\title{
DIATOMITE DEPOSIT IN THE BASIN OF LAKE SOIJÄRVI, CENTRAL FINLAND
}

\author{
TUULIKKI GRÖNLUND
}

\begin{abstract}
GRÖNLUND, TUULIKKI, 1986: Diatomite deposit in the basin of Lake Soijärvi, central Finland. Bull. Geol. Soc. Finland 58, part 2, 35-45.

Diatomite and underlying diatomaceous gyttja are met with in the overgrown Soijärvi basin at Karttula. Diatomite is considered a material containing abundant diatoms and with a $\mathrm{SiO}_{2}$ content of $60 \%$; diatomaceous gyttja has a $\mathrm{SiO}_{2}$ content of $20-60 \%$.

The diatom stratigraphy of the Soijärvi sequence was studied. The diatomite and the diatomaceous gyttja are dominated by the comparatively small Centrales diatoms, mainly Melosira distans and variations. The diatom flora encountered was on the whole very broken.

The chemical composition, porosity and melting temperature were determined on diatomite in a natural state. Porosity was also determined after ingnition at $700^{\circ} \mathrm{C}$. The distribution in particle size was determined on diatomite treated with hydrogen peroxide. The specific surface area of the diatomite in a natural state is $20,100 \mathrm{~m}^{2} / \mathrm{kg}$ and, when ignited, $28,800 \mathrm{~m}^{2} / \mathrm{kg}$.

Key words: diatomite, diatomaceous gyttja, diatom stratigraphy, particle size distribution, specific surface area, porosity, chemical composition, melting temperature.
\end{abstract}

Tuulikki Grönlund: Geological Survey, SF-02150 Espoo, Finland.

\section{Introduction}

Diatomite was found in the course of peat studies in Lake Soijärvi, Karttula $\left(62^{\circ} 40^{\prime} \mathrm{N}, 27^{\circ}\right.$ $05^{\prime} \mathrm{E}$ ) (Fig. 1). The diatomite was established by microscopie examination of samples in a natural state based on the ratio of diatom frustules to mineral matter. Diatomite is considered a material in which almost the whole field of view in a preparation made from it is covered with diatoms and in which no mineral grains are visible. Diatomaceous gyttja in contrast is a material that contains diatoms in abundance but in markedly smaller proportions than in diatomite; mineral matter may be present. The microscopic determination of diatomite and diatomaceous gyttja was verified by chemical analysis. The $\mathrm{SiO}_{2}$ content of the sample is decisive: diatomite assaying over $60 \% \quad \mathrm{SiO}_{2}$ and diatomaceous gyttja 20-60\% $\mathrm{SiO}_{2}$ (Grönlund 1982).

The purpose of this paper is to describe the diatom stratigraphy from the diatomite deposit found in the basin of Lake Soijärvi and to discuss some chemical and physical properties of diatomite material for various applications.

\section{Description of the site}

Soijärvi is an overgrown lake basin in the middle of which there is an open quagmire with 


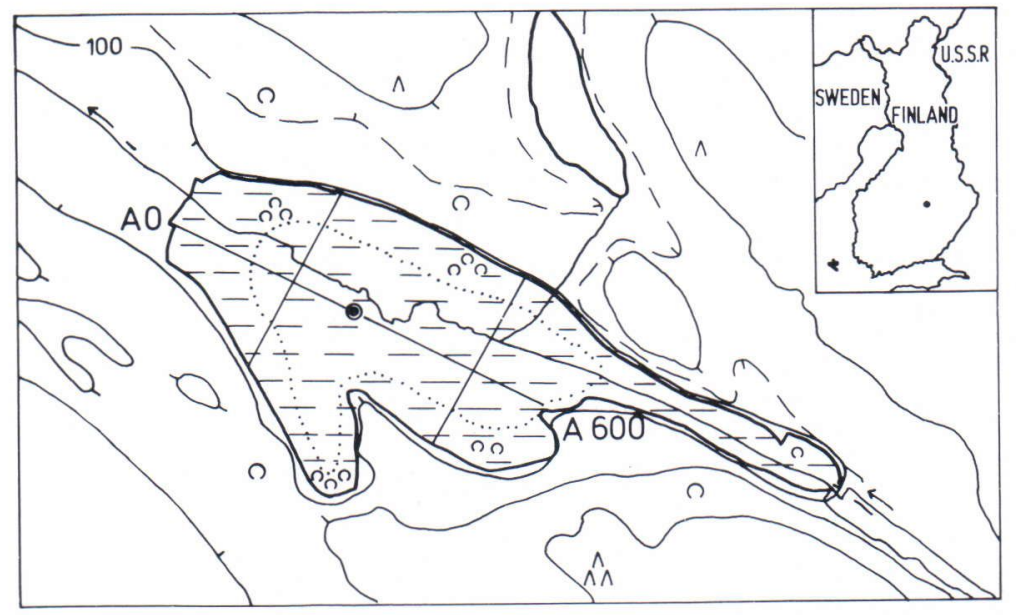

Fig. 1. Soijärvi, Karttula, study lines, sampling point on line $\mathrm{AO}-\mathrm{A} 600$.

\section{SOIJÄRVI, Karttula}

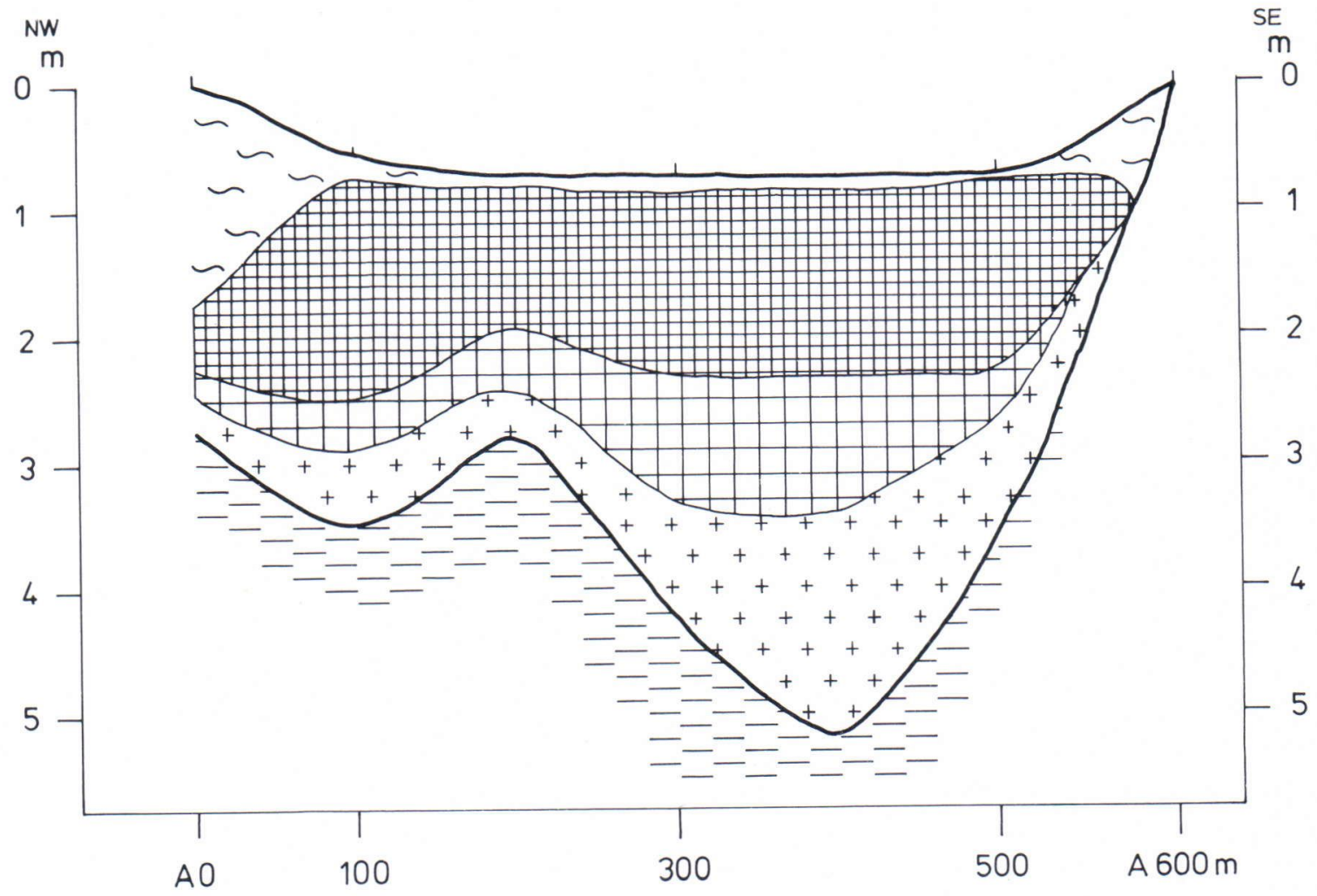

Fig. 2. The sequence at Soijärvi. Symbols explained in Fig. 3. 
a thin layer of peat $(10-30 \mathrm{~cm})($ Fig. 1). The edges are tree mire with birch and spruce and with a layer of peat over one metre deep (Fig. 2). The diatomite deposit was studied from a profile taken at point A 300 (Fig. 1). The layer of diatomite beneath the peat is $130 \mathrm{~cm}$ deep (30$160 \mathrm{~cm}$ ) at the study point. At a depth of $160 \mathrm{~cm}$ the diatomite grades into diatomaceous gyttja that constitutes a layer $95 \mathrm{~cm}$ thick underlain by gyttja clay from a depth of $255 \mathrm{~cm}$ downwards. There is an estimated $187,500 \mathrm{~m}^{3}$ of diatomite and $6,800 \mathrm{~m}^{3}$ of diatomaceous gyttja at Soijärvi. Determined at a depth of $70 \mathrm{~cm}$, the dry density of the diatomite is $0.17 \mathrm{~g} / \mathrm{cm}^{3}$; at a depth of $230 \mathrm{~cm}$ the dry density of the diatomaceous gyttja is $0.29 \mathrm{~g} / \mathrm{m}^{3}$. The content of organic matter in the diatomite is high, the losses on ignition varying between $24 \%$ and $42 \%$ (Fig. 3). The losses are notably smaller for the diatomaceous gyttja and the gyttja clay.

\section{Methods}

\section{Diatom analysis}

Organic matter was removed from the diatom samples by keeping the material in a sand bath in a $30 \%$ solution of hydrogen peroxide for 24 hours at $50^{\circ} \mathrm{C}$. Mineral matter was then eliminated by repeated suspending and decanting. Slides were prepared using Clophenharz (Clophen $\mathrm{W}+$ Clophen A60 $=5: 1$ ) (index of refraction 1.66) as a mounting medium.

Diatoms were taken for analysis at $20 \mathrm{~cm}$ intervals, at least 500 frustules being named at each sampling depth.

\section{Particle size distribution}

The distribution of particle size in the Soijärvi diatomite was determined from a sample taken at a depth of $100-105 \mathrm{~cm}$ and from which the humus had been removed with hydrogen peroxide. First the sample was wetscreened on $62 \mu \mathrm{m}$ mesh. The material that passed the mesh was studied with an automatic particle size analyser (Sedigraph 5000 D) using accelerated sedimentation and the X-ray technique. For the analysis the density of the diatomite was determined as $1.897 \mathrm{~g} / \mathrm{cm}^{3}$; the density of the water was 0.9951 $\mathrm{g} / \mathrm{cm}^{3}$.

\section{Specific surface area and porosity}

The specific surface areas from the material in a natural state and from diatomite ignited at $700^{\circ} \mathrm{C}$ were determined at the laboratory of Engineering Geology, Tampere University of Technology on a sample taken from a depth of $95 \mathrm{~cm}$ using the nitrogen adsorption method, whereby the amount of $\mathrm{N}_{2}$ adsorped onto the surface of the sample is measured at low temperature and pressure. This method gives the specific surface accurately, the irregularities in shape and porosity included (Nieminen 1982).

The porosity of the Soijärvi diatomite was also investigated at the Tampere University of Technology on samples taken from the same depth $(95 \mathrm{~cm})$. This was done using a mercury porosimeter according to a method described in detail by Kellomäki (1982) and by Nieminen and Kellomäki (1982, 1984). Porosity is closely related to the surface area of the particles.

\section{Chemical composition}

The sample was dried at $110^{\circ} \mathrm{C}$ and ground in an agate mortar. One portion $(0.2 \mathrm{~g})$ was fused with sodium hydroxide. The cooled cake was dissolved in hydrochloric acid and an aliquot was taken to measure silica colorimetrically as molybdenum blue. One portion $(0.5 \mathrm{~g})$ was decomposed by treatment with hydrofluoric-nitric-perchloric acid, after which aliquots were taken for the determination of aluminium, calcium, magnesium, sodium and potassium by atomic adsorption spectrophotometer. A nitrous oxide acetylene flame was used for aluminium and calcium, and an air-acetylene flame for magnesium, sodium and potassium. Total iron was analysed 
colorimetrically using the $1.14-\mathrm{HCl}$ method. One portion $(1.0 \mathrm{~g})$ of the sample was heated for $1 \mathrm{hr}$ at $1000^{\circ} \mathrm{C}$ and loss on ignition was measured by weighing.

\section{Melting temperature}

The sintering, softening, fusion and fluid temperatures of the ashes were determined on the Soijärvi diatomite (depth $120 \mathrm{~cm}$ ) and underlying diatomaceous gyttja (depth $200 \mathrm{~cm}$ ) with a Leitz Wetzlar heating microscope (DIN 51731).

\section{Results}

\section{Diatom stratigraphy}

Diatoms were abundant throughout the sequence except in the basal gyttja clay. All the diatoms encountered were fresh-water species. Altogether 144 species and 179 taxa of 32 different diatom genera were named from the profile studied. The diatomite contains 99 species and 156 taxa from 25 diatom genera.

The diatom succession is presented in Fig. 3,
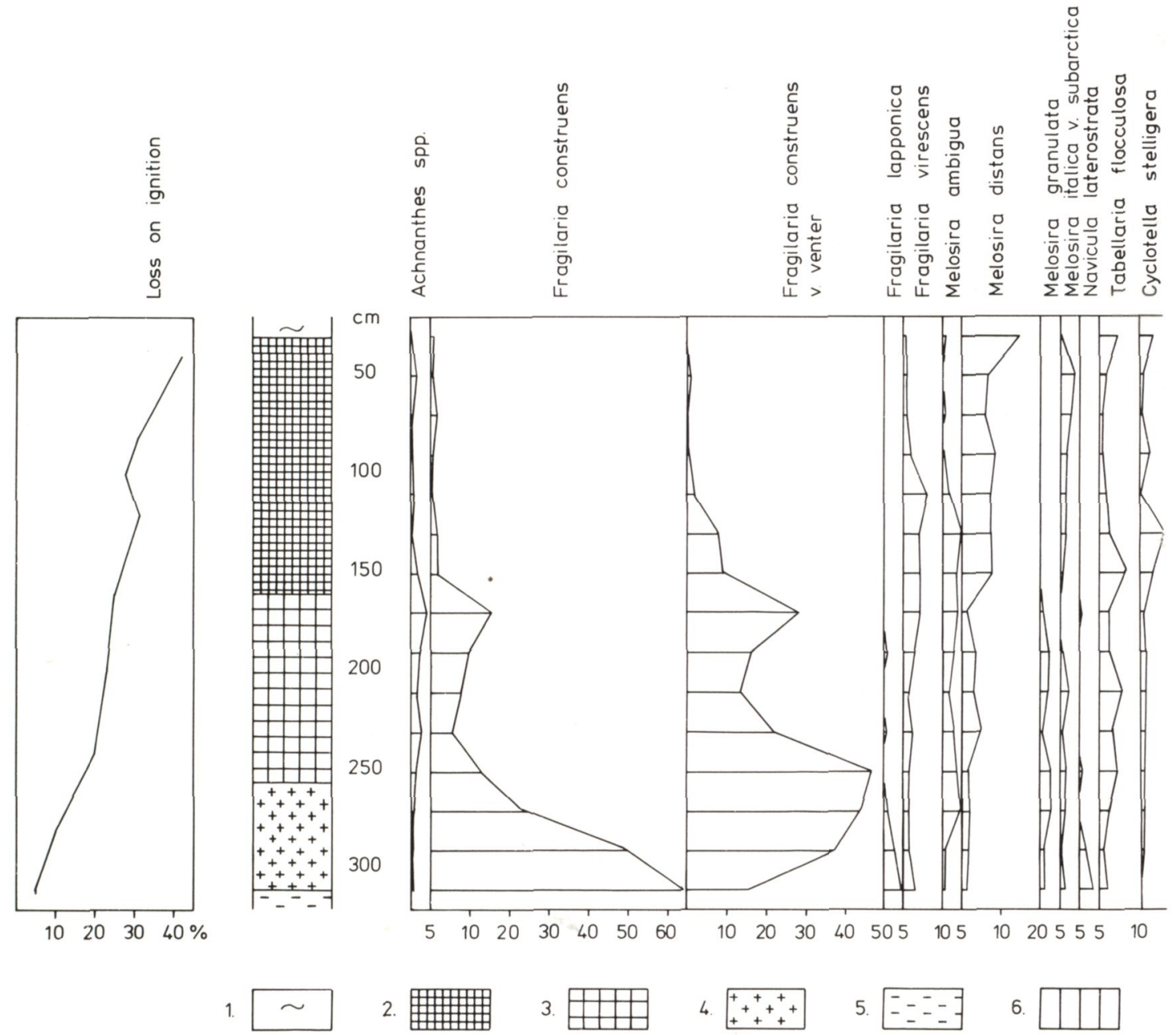

2 .

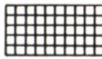

3.
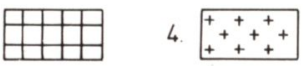

5.

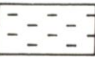

6

Fig. 3. Diatom diagram of Soijärvi, selected species, $\mathrm{pH}$ spectrum of diatoms and curve for loss on ignition. $1=$ peat, $2=$ diatomite, $3=$ diatomaceous gyttja, $4=$ gyttja clay, $5=$ clay, $6=$ acf. + acb., $7=$ ind. + unknown, $8=$ alkf. + alkb. 
which gives the loss on ignition curve and the depth and stratigraphic sequence followed by the names of the individual diatoms that account for more than $2 \%$ of the whole species. The $\mathrm{pH}-$ spectrum of the diatoms is also presented, the diatoms being divided into ecological groups according to their pH-requirements (Meriläinen 1967, 1969, Miller 1971, Foged 1973, 1980, Mölder \& Tynni 1967-1973, Tynni 1975-1980).

The Centrales and Pennales ratio is shown in the diagram reflecting roughly the planktonic and littoral ratio in the diatom flora.
The diatom analysis was hampered by the abundance of broken frustules, which in both the diatomite and diatomaceous gyttja deposits occur in such profusion that they carpet the preparation in an even layer. This shows up particularly clearly in Figs. 4 and 5. Some of the diatoms, however, are very well preserved, and the dominant species in the diatomite, Melosira distans and its variations, also occurs in well preserved chains. Because the diatom flora is so decomposed some species may have escaped analysis and thus the stronger species are over repre-
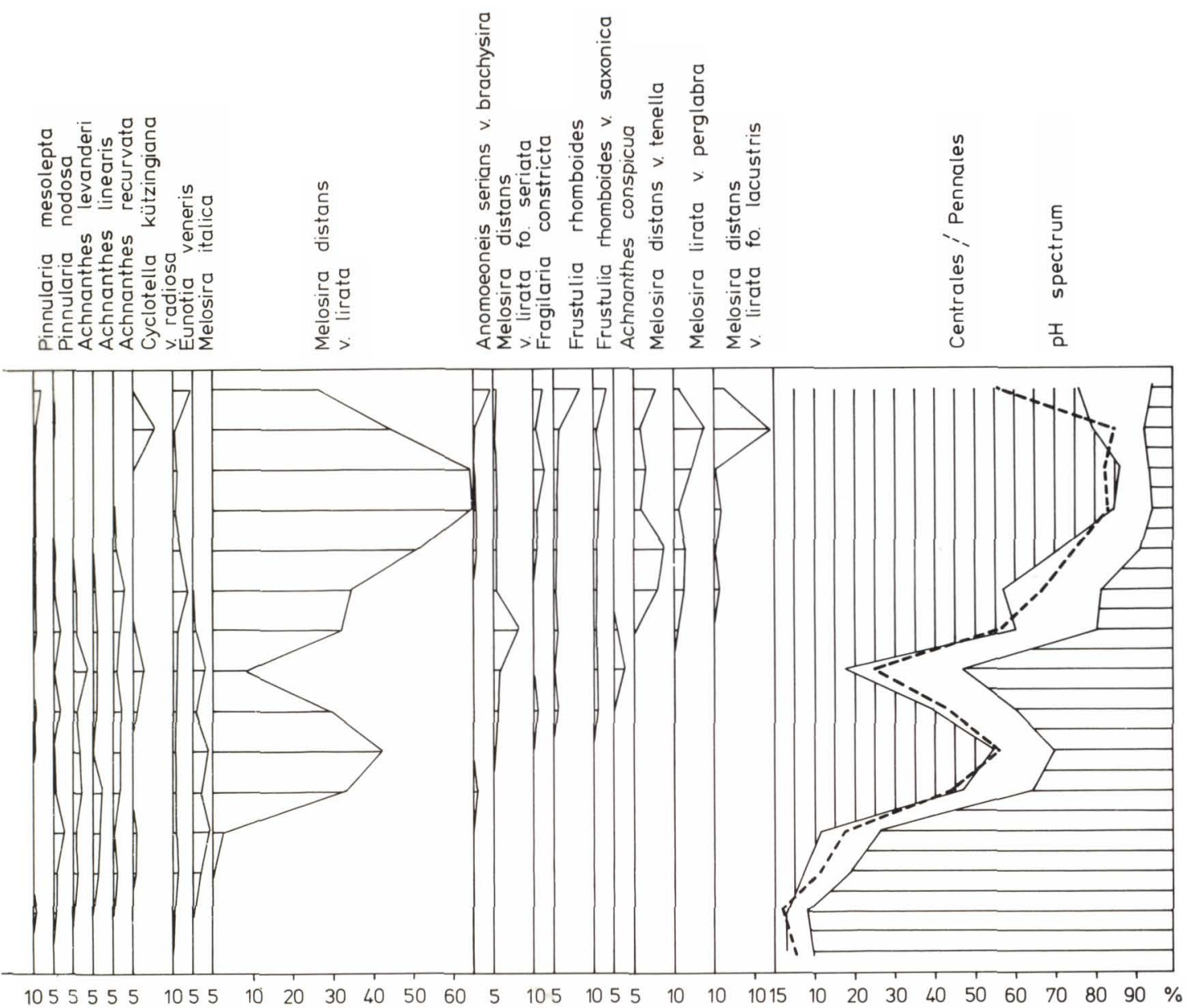

7.

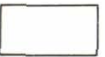

8

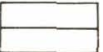



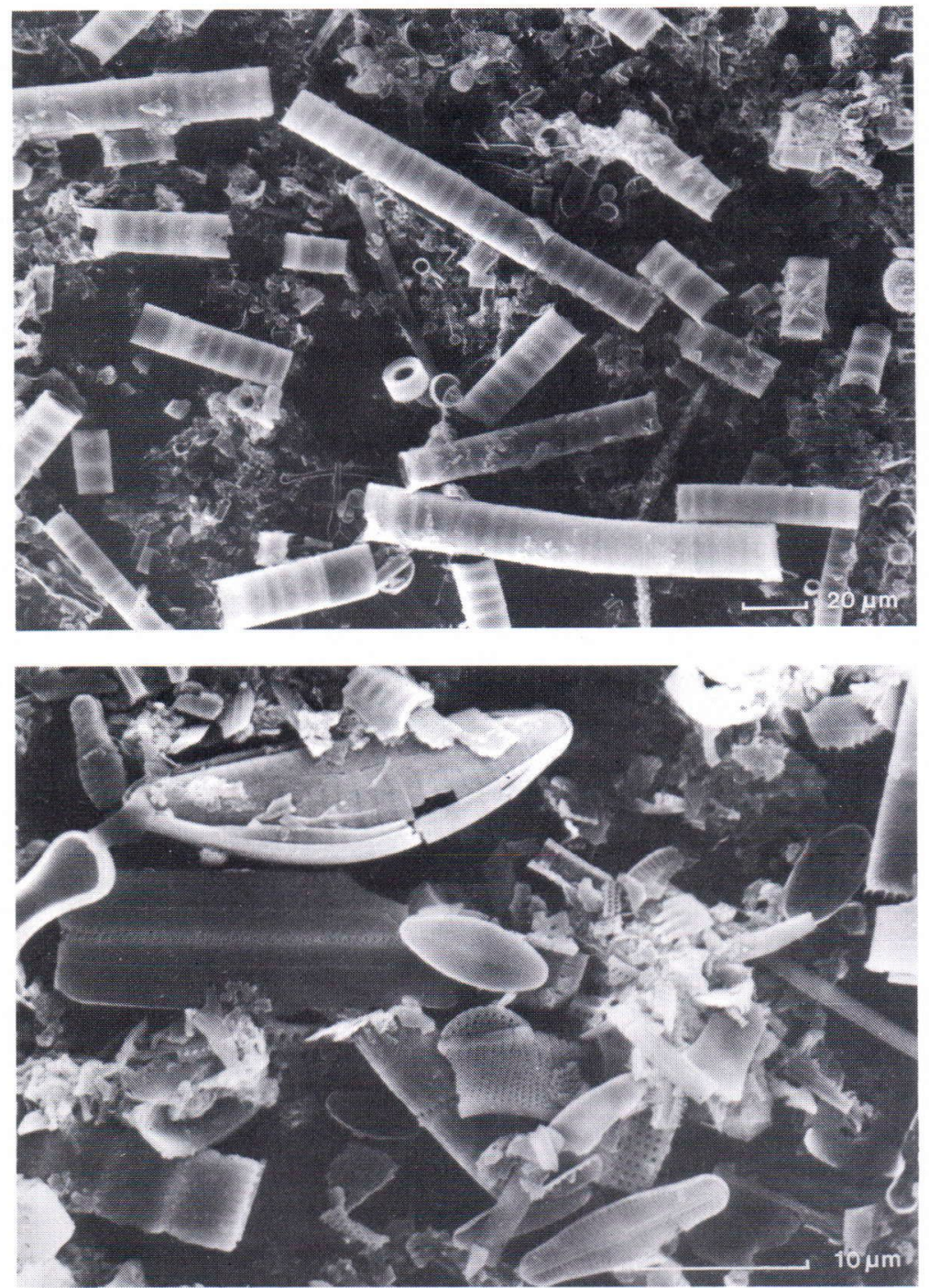

Fig. 4. Overall picture of Soijärvi diatomite. Uppermost are chains of $\mathrm{Me}$ losira distans var. lirata. Although the chains break easily, some long ones can be seen. In the figure the longest chains comprise more than ten individuals. Electron microscope image by K. Hokkanen.

Fig. 5. Broken diatom flora in Soijärvi diatomite. Electron microscope image by $\mathrm{K}$. Hokkanen.

sented. This is implied by the relatively small number of species in the diatom flora.

In the succession of diatoms the diatomaceous gyttja and the diatomite are distinguished clearly from the underlying gyttja clay, which is characterized by alkaliphilic flora. The dominant species in the gyttja clay are Fragilaria construens and $F$. construens var. venter.

The diatomaceous gyttja and particularly the diatomite are characterized by the abundance of
Melosira species. Altogether 16 different taxa of Melosira species were distinguished. They were determined according to Mölder and Tynni (1967) and Florin (1980). The most common are Melosira distans and $M$. distans var. lirata. Also present in appreciable numbers were $M$. lirata var. lacustris and $M$. lirata var. perglabra, and M. distans var. tenella (Nygaard) M-B Florin, which is a small and squat, broad-celled diatom. All the above Melosira species are acidophilic 
in their $\mathrm{pH}$ ecology. Melosira species calling for more alkaline water were also encountered. The majority of these were $M$. ambigua and M. granulata, which occurred in profusion in the diatomaceous gyttja. Littoral species met with in the deposit are diatoms of Frustulia rhomboides and Pinnularia genera. Also worth mentioning is Cyclotella stelligera, which, indifferent in $\mathrm{pH}$ ecology, occurs abundantly in the diatomite in particular.

\section{Particle size}

The largest particle size measurable with the particle size analyser is $60 \mu \mathrm{m}$, which, according to the size classification, is the upper limit of fine sand. The dominant species in the Soijärvi diatomite, Melosira distans and its variations, is box-like in shape and $4-30 \mu \mathrm{m}$ in diameter (Hustedt 1930). The Melosira species may, however, form chains comprising several individuals, in which case the length of the chains exceeds $60 \mu \mathrm{m}$ (Fig. 4). Many Pinnularia species are also over $60 \mu \mathrm{m}$ in length. Other species usually exceeding $60 \mu \mathrm{m}$ at Soijärvi include Cymbella hauckii, C. turgida, Eunotia robusta, E. lapponica, E. lunaris, Frustulia rhomboides, Navicula radiosa, Stauroneis phoenicenteron and Tabellaria fenestrata and T. flocculosa. Although the above diatoms are so large that they dominate

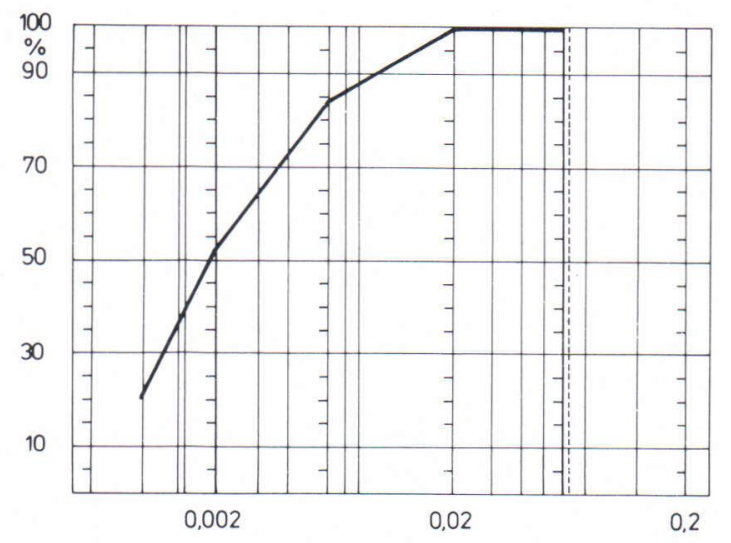

Fig. 6. Distribution of particle size in Soijärvi diatomite at depth of $100-105 \mathrm{~cm}$. the field of view of the microscope their proportion of the Soijärvi species is low, because too little material remained on the mesh during wetscreening for it to be weighed. The distribution of particle size obtained with the analyser is given in Fig. 6. This shows that $52 \%$ of the particles in Soijärvi diatomite are smaller than $2 \mu \mathrm{m}, 47 \%$ are from 2 to $20 \mu \mathrm{m}$, and not even one per cent is from 20 to $60 \mu \mathrm{m}$. The large number of fragments in the Soijärvi diatomite is thus clearly reflected in the distribution of particle size.

\section{Specific surface area and porosity}

The total calculated area, or specific surface area, of particles from material in a natural state at Soijärvi is $20,100 \mathrm{~m}^{2} / \mathrm{kg}$ and from diatomite ignited at $700^{\circ} \mathrm{C} 28,800 \mathrm{~m}^{2} / \mathrm{kg}$.

The porosity of the Soijärvi diatomite was determined from both the material in a natural state and the samples ignited at $700^{\circ} \mathrm{C}$. The results of the porosity determinations are given in Table 1 and as diagrams in Figs. 7 and 8. Various densities can be obtained for porous materials, depending on what is included in their volume. The geometric volume includes the real volume of the matter and all the pores. Corresponding to this is the bulk density, or weight by volume, of pulverous material, which is obtained with a mercury porosimeter at minimum pressure. At maximum pressure, the mercury fills all the pores with which it comes in contact. This gives the apparent density (Nieminen and Kellomäki 1982). The weight by volume of dried Soijärvi diatomite in a natural state was $0.298 \mathrm{~g} / \mathrm{cm}^{3}$ and of ignited diatomite $0.258 / \mathrm{cm}^{3}$. The geometric volume, which was used when calculating the weight by volume, includes all the pores not filled with mercury at minimum pressure (c. 0.03 atm). In the calculation, the pore volume filled with mercury at maximum pressure was subtracted from the geometric volume. The porosity percentage is the percentage of the pore volume of the geometric volume. The apparent density of 


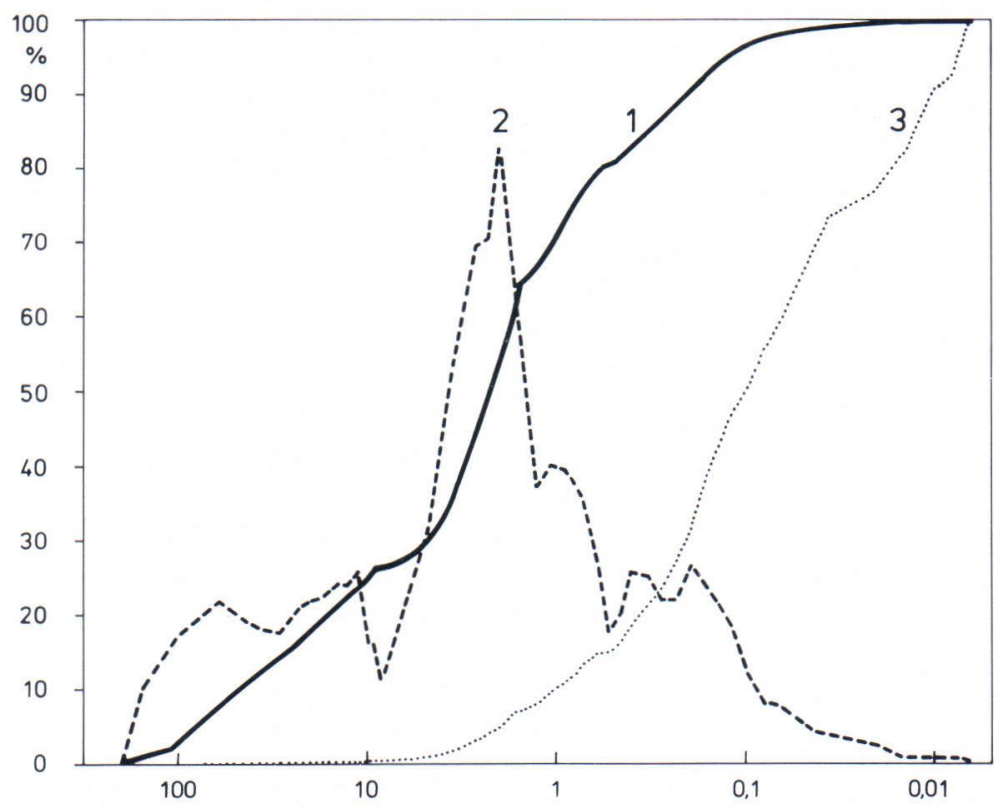

Fig. 7. Porosity curves of Soijärvi diatomite in a natural state $1=\mathrm{cu}$ mulative volume, 2 = pore volume distribution, 3 = cumulative surface area.

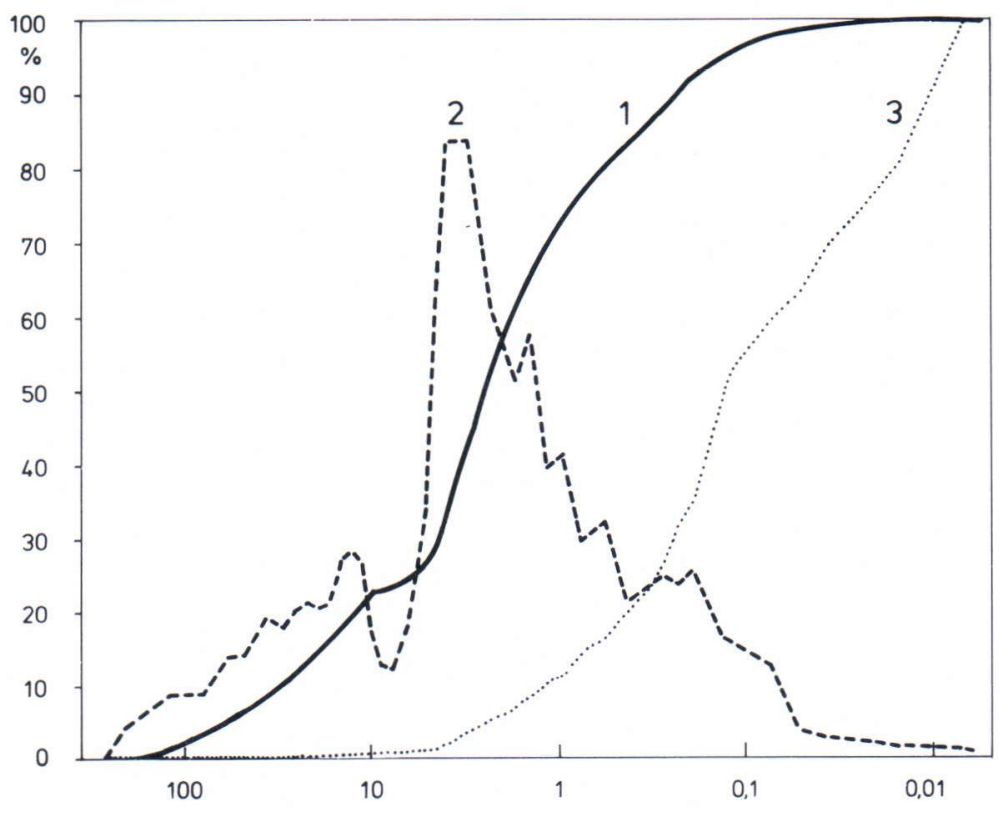

Fig. 8. Porosity curves of Soijärvi diatomite ignited at $700^{\circ} \mathrm{C}, 1=\mathrm{cu}$ mulative volume, 2 = pore volume distribution, 3 = cumulative surface area.

the Soijärvi raw diatomite is $0.9233 \mathrm{~g} / \mathrm{m}^{3}$ and of ignited diatomite $1.5499 \mathrm{~g} / \mathrm{m}^{3}$; the figures for porosity are $68.64 \%$ and $83.34 \%$, respectively.

The graph presents three curves as a function of pore diameter:
1 = cumulative volume curve, or pore volume per pore diameter

$2=$ distribution curve of pore volume, which is a derivative of the curve in 1 . It indicates the distribution of the volume of the pores 
according to diameter

3 = cumulative surface area curve.

Table 1 reveals that ignition, or the destruction of the organic matter, affected the results. The total pore volume of ignited Soijärvi diatomite is $3.2 \mathrm{dm}^{3} / \mathrm{kg}$ and of material in a natural state $2.3 \mathrm{dm}^{3} / \mathrm{kg}$. The table also makes it plain that about half the pore volume of the material in a natural state consists of pores of less than $1 \mu \mathrm{m}$, whereas in the ignited diatomite about $2 / 3$ of the total volume comprises pores of less than $1 \mu \mathrm{m}$.

\section{Chemical composition}

A chemical analysis was performed on the Soijärvi diatomite on a sample taken from a depth of $100-105 \mathrm{~cm}$ from the middle of the diatomite layer. The result is as follows:

\begin{tabular}{|c|c|c|c|c|c|}
\hline $\mathrm{SiO}_{2}$ & - & $65.3 \%$ & $\mathrm{MgO}$ & - & $0.3 \%$ \\
\hline $\mathrm{Al}_{2} \mathrm{O}_{3}$ & - & $3.0 \%$ & $\mathrm{Na}_{2} \mathrm{O}$ & - & $0.2 \%$ \\
\hline $\mathrm{Fe}_{2} \mathrm{O}_{3}$ & - & $1.3 \%$ & $\mathrm{~K}_{2} \mathrm{O}$ & - & $0.2 \%$ \\
\hline $\mathrm{CaO}$ & - & $0.6 \%$ & $\begin{array}{l}\text { Loss or } \\
\text { ignition }\end{array}$ & & $28.2 \%$ \\
\hline
\end{tabular}

The organic matter in the Soijärvi diatomite is appreciable, which was already apparent in the other loss on ignition determinations (Fig. 3). Other impurities are few, however; only the aluminium content reaches a few per cent (3).

\section{Melting temperature}

The results of the analyses are as follows:

$\begin{array}{lrr} & & \text { depth } 200 \mathrm{~cm} \\ \text { sintering temperature } & 1140^{\circ} & 1110^{\circ} \\ \text { softening temperature } & 1360^{\circ} & 1150^{\circ} \\ \text { fusion temperature } & >1460^{\circ} & >1460^{\circ} \\ \text { fluid temperature } & >1460^{\circ} & >1460^{\circ}\end{array}$

Table 1. Results of porosity determinations on Soijärvi diatomite, 1) diatomite in a natural state, 2) diatomite ignited at $700^{\circ} \mathrm{C} . \mathrm{D}=$ diameter $(\mu \mathrm{m})$ of filled pores, $\mathrm{V}=$ filled pore volume $\left(\mathrm{dm}^{3} / \mathrm{kg}\right.$ of sample), $\mathrm{A}=$ cumulative surface area $\left(\mathrm{m}^{2} / \mathrm{kg}\right.$ of sample) \begin{tabular}{ll}
\hline $\begin{array}{l}\text { 1. Diatomite in a natural } \\
\text { state }\end{array}$ & $\begin{array}{l}\text { 2. Diatomite ignited } \\
\text { at } 700^{\circ} \mathrm{C}\end{array}$
\end{tabular}

\begin{tabular}{|c|c|c|c|c|c|}
\hline \multicolumn{2}{|c|}{$\begin{array}{l}\text { Sample weight } \\
\text { Bulk density } \\
\text { Porosity } \%\end{array}$} & \multirow{2}{*}{$\begin{array}{l}.2460 \\
.2896 \\
68.64 \\
\mathrm{~A}\end{array}$} & \multicolumn{2}{|c|}{$\begin{array}{l}\text { Sample weight } \\
\text { Bulk density } \\
\text { Porosity } \%\end{array}$} & $\begin{array}{l}.19 \\
.258149 \\
83.3448 \\
\end{array}$ \\
\hline D & V & & $\mathrm{D}$ & V & A \\
\hline UM & $\mathrm{CDM} / \mathrm{KG}$ & $\mathrm{SQM} / \mathrm{KG}$ & UM & $\mathrm{CDM} / \mathrm{KG}$ & $\mathrm{SQM} / \mathrm{KG}$ \\
\hline 200.5424 & 0.0000 & 0 & 257.843 & 0 & 0 \\
\hline 112.8051 & .0457 & 1 & 138.838 & .025045 & .555049 \\
\hline 85.9467 & .1046 & 4 & 72.196 & .118396 & 4.45556 \\
\hline 69.4185 & .1600 & 7 & 53.0853 & .184424 & 8.80888 \\
\hline 51.5680 & .2251 & 11 & 45.1225 & .210608 & 10.9559 \\
\hline 40.1085 & .2778 & 16 & 39.237 & .249314 & 14.6444 \\
\hline 32.8160 & .3130 & 20 & 31.6649 & .301682 & 20.5507 \\
\hline 25.7840 & .3614 & 26 & 28.6492 & .342665 & 26.0002 \\
\hline 22.5610 & .3948 & 32 & 24.7247 & .385925 & 32.4942 \\
\hline 19.6183 & .4273 & 38 & 21.7458 & .426908 & 39.566 \\
\hline 16.7119 & .4669 & 47 & 20.5102 & .447399 & 43.4487 \\
\hline 15.0407 & .4924 & 53 & 19.4075 & .464476 & 46.8737 \\
\hline 13.6733 & .5196 & 61 & 17.5233 & .498628 & 54.2784 \\
\hline 12.0325 & .5522 & 71 & 15.9726 & .527089 & 61.0526 \\
\hline 10.4328 & .5768 & 80 & 15.2958 & .543026 & 65.139 \\
\hline 9.3517 & .6181 & 97 & 14.2118 & .570347 & 72.5643 \\
\hline 9.5740 & .6181 & 97 & 13.079 & .603363 & 82.2617 \\
\hline 7.2685 & .6392 & 107 & 12.0327 & .637516 & 93.0549 \\
\hline 5.3424 & .6885 & 139 & 11.5699 & .652316 & 98.0732 \\
\hline 4.1309 & .7834 & 220 & 10.7435 & .684189 & 109.516 \\
\hline 3.3686 & .8995 & 346 & 10.0272 & .713789 & 120.976 \\
\hline 2.8447 & 1.0367 & 524 & 9.75622 & .7229 & 124.661 \\
\hline 2.4608 & 1.1430 & 685 & 8.03964 & .735421 & 129.864 \\
\hline 2.1682 & 1.2477 & 867 & 5.25021 & .832187 & 191.139 \\
\hline 1.8392 & 1.3576 & 1088 & 4.58921 & .897077 & 244.137 \\
\hline 1.5975 & 1.5176 & 1462 & 4.07917 & 1.0075 & 346.397 \\
\hline 1.3577 & 1.5633 & 1587 & 3.33804 & 1.24315 & 603.124 \\
\hline 1.1805 & 1.6099 & 1735 & 2.44535 & 1.59265 & 1098.37 \\
\hline .9873 & 1.6979 & 2062 & 1.94849 & 1.83172 & 1539.29 \\
\hline .8484 & 1.7621 & 2343 & 1.77697 & 1.91027 & 1708.33 \\
\hline .7756 & 1.7972 & 2517 & 1.47392 & 2.06509 & 2092.66 \\
\hline .6620 & 1.8597 & 2867 & 1.2677 & 2.17325 & 2410.06 \\
\hline .5774 & 1.9036 & 3152 & .990278 & 2.32579 & 2958.79 \\
\hline .4844 & 1.9124 & 3219 & .896978 & 2.38158 & 3195.86 \\
\hline .4483 & 1.9388 & 3446 & .622169 & 2.54437 & 4082.13 \\
\hline .3592 & 1.9915 & 3975 & .499917 & 2.62292 & 4648.88 \\
\hline .2996 & 2.0399 & 4568 & .448967 & 2.65935 & 4956.91 \\
\hline .2569 & 2.0707 & 5013 & .359573 & 2.73335 & 5698.15 \\
\hline .2117 & 2.1173 & 5816 & .300363 & 2.80051 & 6518.89 \\
\hline .1801 & 2.1595 & 6684 & .256428 & 2.85858 & 7358.47 \\
\hline .1386 & 2.2272 & 8414 & .22538 & 2.90753 & 8174.63 \\
\hline .1060 & 2.2747 & 9996 & .200145 & 2.95193 & 9012.31 \\
\hline .0901 & 2.2931 & 10754 & .090306 & 3.14204 & 14872.2 \\
\hline .0721 & 2.3142 & 11808 & .060131 & 3.17961 & 16953.9 \\
\hline .0601 & 2.3274 & 12613 & .045263 & 3.19213 & 17923.5 \\
\hline .0258 & 2.3547 & 15637 & .030109 & 3.20807 & 19737.7 \\
\hline .0180 & 2.3582 & 16300 & .025808 & 3.21149 & 20229.9 \\
\hline .0116 & 2.3626 & 17543 & .020067 & 3.21604 & 21060.7 \\
\hline .0090 & 2.3670 & 19274 & .012065 & 3.22287 & 22798.2 \\
\hline .0072 & 2.3679 & 19712 & .007206 & 3.22628 & 24499.5 \\
\hline .0060 & 2.3705 & 21321 & .005956 & 3.22856 & 25897.8 \\
\hline
\end{tabular}




\section{Discussion}

Only a few diatom floras of diatomite deposits have been described in Finland. The diatom succession from Vähä-Komujärvi in Pyhäjärvi, which is characterized by Melosira distans and M. distans var. lirata, is very similar to that found in Soijärvi, whereas the diatomite from Rätäksuo mire in Hollola is dominated by alkaliphilous Pennales diatoms, especially Fragilaria construens and F. construens var. venter (Grönlund 1982).

The diatom floras of the diatomite occurrences situated in a secondary position in Haapajärvi and described by Aario (1966) also differ from the flora in Soijärvi. According to Aario, the occurrences in Haapajärvi are interglacial or interstadial, containing a considerable amount of Melosira islandica and its resting spores.

The evolution of the Soijärvi basin is typical of such basins in Finland. The diatomite often deposited in oligotrophic lakes when the changing and silica-bearing water provided the right conditions for a rich diatom flora. The diatoms indicate that as the diatomaceous gyttja started to deposit in the Soijärvi basin the water in the basin was changing from neutral-alkaline to more acidic. As deposition continued the basin became alkaline again but only for a brief period, because the water in the Soijärvi basin was already acidic when the diatomite was deposited. The dominant species grew so rapidly that it hindered competition by other diatoms. Likewise, the diatoms obviously disintegrated very quickly at the sedimentation stage at the same time as the organic matter was deposited.

The use to which diatomite is put depends not only on its physical and chemical properties but also on its purity. It has a wide range of applications (e.g. Mölder 1960), one of the most important of which is as a filtration medium: $64 \%$ of the 687,000 metric tons of diatomite produced in the USA in 1981 went for filtration mediums (Meisinger 1981). The next most important application in the USA is as a filler $(23 \%)$. This has increased substantially in the last few years and has great promise, particularly in the building materials sector. Diatomite is also used as an insulator ( $2 \%)$, as an absorption and abrasive material, and as an additive in fertilizers (Meisinger 1981). According to Mölder (1960), the diatomite containing abundant frustules of Melosira species, especially Melosira distans, is very suitable for use as a polishing material.

In durability, diatomite is comparable with quartz, the only substances being able to dissolve it are strong alkalies and hydrofluoric acid. The Soijärvi diatomite is a rather high-quality material in terms of chemical composition and physical properties. Thanks to its high melting temperature, it makes an excellent heat insulator.

Particle size, specific surface area and the porosity have not been determined before from diatomite and thus there are no data with which to compare the results obtained from the Soijärvi diatomite.

The particle size distribution obtained does not perhaps entirely correspond to the true nature of the diatomite of Soijärvi. More analyses of different kinds of diatomite materials would be needed. The methods used may accentuate somewhat the proportion of small particles, because the big diatoms and diatom chains are inclined to break during wetscreening. Moreover, the elongated ones and those under $62 \mu \mathrm{m}$ in diameter may pass through the mesh. In the analyser the shape of the elongated diatoms may affect their sedimentation rate and mode and thus alter the result. The lightness of the diatomite may also affect its sedimentation process.

Many physical and chemical properties of powdered materials, e.g. cation exchange capacity of soils and their ability to retain water, depend on their large surface areas. Large surface areas are possible only because such materials are porous. Determination of the porosity distribution of the specific surface area gives us more classification criteria for the material. We can also establish how the materials behave and how appropriate they are for various purposes. Thus, 
in his study on the distribution of pores in active carbon, Ranta (1981) states that a high microporosity is beneficial when gases and vapours are being adsorbed. But carbon should also have pores of large diameter, when solutions are being adsorbed. Thus, different pore distributions are suitable for different purposes.

The specific surface area of diatomite is important when assessing the material for technical potential, especially if it is to be used as a fil-

\section{References}

Aario, R., 1966. Kieselgur in fluvioglazialen Ablagerungen in Haapajärvi in Ostbottnien. C. R. Soc. géòl. Finlande $38,3-30$.

Florin, M-B., 1980. The Taxonomy of some Melosira Species. A Comparative Morphological Study. II. 6th Diatom-symposium 1980, 43-67.

Foged, N., 1973. Diatoms from Southwest Greenland. Medd. Gronland 194 (5) 84 p.

_, 1980. Diatoms in Öland, Sweden. Bibl. Phycol. 49. 193 p.

Grönlund, T., 1982. On Finnish diatomites. In: Håkansson H. (ed.): Rapport från diatomésymposium i Lund, maj 1981. Univ. of Lund, Departm. of Quaternary Geology, report 22, 23-52.

Hustedt, H., 1930. Bacillariophyta (Diatomeae): Süsswasserflora, 10. Jena, $466 \mathrm{pp}$

Kellomäki, A., 1982. Huokoisuus ja sen mittaaminen. Partikkelipäivät 1982, luentomoniste. Oy Tamro Ab, Helsinki, $20 \mathrm{pp}$.

Meisinger, A. C., 1981. Diatomite. Minerals Yearbook. Vol. I, 309-311.

Meriläinen, J., 1967. The diatom flora and the hydrogen-ion concentration of the water. Ann. Bot. Fennici 4, 51-58.

-, 1969. The diatoms of the meromictic Lake Valkiajärvi, in the Finnish Lake District. Ann. Bot. Fennici 6, 77-104.

Miller, U., 1971. Diatom floras in the sediments at Leveäniemi. In: Jan Lundqvist: The interglacial deposit at Leveäniemi mine, Svappavaara, Swedish Lapland. Sveriges Geol. Undersökn. C 658, 104-163.

Mölder, K., 1960. Piimaan käyttö teollisuudessa. In K. Virkkala: Sovellettua maaperägeologiaa. Geologiliiton julkaisuja N:o 3, 3, 41-46.

Mölder, K. \& Tynni, R., 1967. Über Finnlands rezente und subfossile Diatomeen. I. Comt. Rend. géol. Finlande 39, tration medium because then its large specific surface area has a marked impact on its efficiency.

Acknowledgements. The diatomite and diatomaceous gyttja were sampled and evalued by Mr. Jukka Leino. The material was prepared by Mrs. Eila Paavilainen. The surface area and porosity were determined by Dr. Pertti Nieminen. The manuscript was read critically by Dr. Heikki Ignatius, Professor Raimo Kujansuu and Dr. Risto Tynni and translated into English by Mrs. Gillian Häkli.

I express my cordial thanks to all the above persons for their help.

$199-217$

—, 1968. Über Finnlands rezente und subfossile Diatomeen II. Bull. Geol. Soc. Finland 40, 151-170.

—, 1969. Über Finnlands rezente und subfossile Diatomeen III. Bull. Geol. Soc. Finland 41, 235-251.

-, 1970. Über Finnlands rezente und subfossile Diatomeen IV. Bull. Geol. Soc. Finland 42, 129-144.

-, 1971. Über Finlands rezente und subfossile Diatomeen V. Bull. Geol. Soc. Finland 43, 203-220.

-, 1972. Über Finnlands rezente und subfossile Diatomeen VI. Bull. Geol. Soc. Finland 44, 141-149.

—, 1973. Über Finnlands rezente und subfossile Diatomeen VII. Bull. Geol. Soc. Finland 45, 159-179.

Nieminen, $P$., 1982. Ominaispinta-ala ja sen käyttö maalajien luokituksessa. Partikkelipäivät 1982, luentomoniste. Oy Tamro Ab, Helsinki, 15 pp.

— \& Kellomäki, A., 1982. Moreenin hienoaineksen huokoisuudesta. Porosity of Finnish tills. Tampereen teknillinen korkeakoulu, Rakennustekniikan osasto, Rakennusgeologian laboratorio, Raportti 10, Tampere, 123 pp.

— \& Kellomäki, A., 1984. Porosity of fine fractions of Finnish tills. Bull. Geol. Soc. Finland 56, Part 1-2, 221-226.

Ranta, J., 1981. Mikrohuokoisuuden merkitys aktiivihiilen adsorptio-ominaisuuksia arvosteltaessa. VTT, Poltto- ja voiteluainelaboratorio, Tiedonanto 39, Espoo, $113 \mathrm{pp}$.

Tynni, R., 1975. Über Finnlands rezente und subfossile Diatomeen VIII. Geol. Surv. Finland Bull. 274, 55 p.

—, 1976. Über Finnlands rezente und subfossile Diatomeen IX. Geol. Surv. Finland Bull. 284, 37 p.

-, 1978. Über Finnlands rezente und subfossile Diatomeen X. Geol Surv. Finland Bull. 296, 55 p.

-, 1980. Über Finnlands rezente und subfossile Diatomeen, XI, Geol. Surv. Finland Bull. 312, 93 p.

Manuscript received 1. February, 1985 